\title{
Political Development Policy Based on Local Potential to Improve People Welfare in Merangin Regency, Jambi Province
}

\author{
Pahrudin $\mathrm{HM}^{1}$, Ratna Dewi ${ }^{2}$ \\ \{pahrudinhm9@gmail.com¹,dratna376@yahoo.com² \\ Universitas Jambi, Indonesia ${ }^{1,2}$
}

\begin{abstract}
Regional autonomy provides more space for regions to develop their territories so that people's welfare can be realized. This effort can be made through policies sourced from local governments, one of which is development based on local potential. This study aims to determine the politics of local potential based development policies carried out by the The Government of Merangin Regency. This study uses a qualitative research approach with the type of library research by reviewing data related to local potential, development policies and community welfare of Merangin Regency 2016-2018. Merangin Regency has the area of rubber was 132,192 hectares, oil palm covering 53,792 hectares, robusta coffee with an area of 10,860 hectares and coconut with an area of 1,658 hectares as well as being the main foundation of people work in this region (79.63\%). Related to this Merangin Regency has a vision and mission that is oriented to the utilization of local potential to improve people's welfare. The establishment of BUMD is one of the strategic efforts to realize the big vision carried out by Merangin Regency.
\end{abstract}

Keywords: Political Policy, Local Government, Local Potential, Welfare, Merangin.

\section{Introduction}

After the reforms initiated since 1998, Indonesia changed the government paradigm from centralized to decentralized. If before, people's affairs were the full responsibility of the central government, so the decentralization system made it a matter of regional government. The determination of the choice for the system, also known as regional autonomy, is certainly not merely to look different from the steps taken by the replaced New Order government. Decentralization was chosen because it was based on rational considerations carried out by all leaders of this nation. Decentralization is believed to be an effective solution to overcome the various problems that arise when Indonesia is in a period of centralization.

According to Stoker [1] and Bird and Vaillancourt [2], a decentralized system was chosen as a system of government because it has several advantages. First, the decentralization policy that forms the basis of post-reform regional management promises economic efficiency, program cost effectiveness, accountability, increased resource mobilization, reduced disparity, increased political participation, and strengthening democracy and political stability. Second, through decentralization, local governments are considered to have better knowledge of the 
needs and preferences of their citizens, so the development process in the decentralization policy model should be more efficient than the centralized policy model in the framework of improving the welfare of local communities.

These are some of the advantages of decentralization that lead to the establishment of a system as a method of managing government in post-reform Indonesia. Stoker and Bird and Vaillancourt's statements above are in line with the research findings conducted by Kisman and Tasar [3] and Witkowski and Kiba-Janiak [4]. Both of these studies show the magnitude of the role of local governments (in Turkey and Poland) in an effort to overcome the social problems faced by society. These studies also emphasize that local governments can better improve people's welfare, compared to when the government is still in a centralized system. In addition, studies conducted by Nak-ai etc. [5], Sharma [6] and Brillo [7] also show that the role played by local governments in collaborating with several stakeholders is able to improve the lives of the people.

Even so, the problem is that after a long time Indonesia implemented a decentralized system it turned out that the results were not in line with expectations. Based on several studies (Hasjimzum [8] ; Tasrin and Wulandari [9] show that decentralization in various regions in Indonesia is still unable to achieve community welfare as the main objective of its implementation with a variety of factors that cause it. This condition must certainly be a concern because after all the decentralization policy was a national consensus as a solution to the problems of the people during the era of centralization. Therefore, it is necessary to find the location of the problems faced in relation to the lack of achievement of the objectives of implementing regional autonomy in Indonesia.

Based on studies conducted by HM [10], Kisman and Tasar [3], Witkowski and Kiba-Janiak [4], Nak-ai etc. [5] , Sharma [6] and Brillo [7] can be concluded that the realization or failure of community welfare is very dependent on the efforts made by the regional government. This is in line with Law Number 32 of 2004 concerning Regional Autonomy which states that the regional government in implementing regional autonomy must fulfill the needs of its region in accordance with the stipulated budget with the aim of improving the welfare of its people. In carrying out autonomy, the regions have obligations such as: improving the quality and life of the people, developing democratic life, realizing justice and equity, improving basic education services, providing health care facilities, and providing decent social facilities and public facilities. Thus, theoretically, as stated earlier that the decentralization policy model should be able to bring a better level of welfare compared to a centralized (centralized) system.

One effort that can be made by local governments in an effort to realize the goal of regional autonomy is to develop development policies that rely on local potential. As is well known that various Indonesian resources, both natural resources and human resources, are spread in various regions throughout the country. Capitalizing on the authority of regional autonomy with all its privileges, local governments can use and process this large local potential as a means of improving community welfare. Merangin Regency of Jambi Province is a worthy example put forward to see how local potential based development policies can be carried out to realize community welfare. Based on BPS (2018) data, Merangin Regency is the largest area in Jambi Province $(7,679 \mathrm{~km} 2 / 15.31 \%)$, one of the regions with the highest population in Jambi Province (377,905 people), total rubber plantation area of 131,413 hectares (the largest in Jambi Province ), and most of the population (79.31\%) work in the agriculture, plantation and forestry sectors. While on the other hand, welfare indicators are relatively not encouraging, such as the still high poverty rate (9.43\%), and the Human Development Index (HDI) which is still below Jambi Province and other districts (68.30) . 
On this basis, research on the political development policies of The Government of Merangin Regency as an effort to improve the welfare of the community is very significant. This is because local governments have far greater opportunities to improve people's welfare through the regional autonomy system. The broad authority granted in the decentralization system is expected to make the regions produce a variety of innovative development programs that are specific to their regions, one of which is through local potential-based development. Through a series of innovative development programs produced by local governments such as this, it is hoped that people's welfare which becomes something rare in the past can become a reality.

\section{Methods}

This study uses a qualitative research approach to find out the development policies based on the local potential of The Government of Merangin Regency in an effort to improve community welfare. The type of research is library research by reviewing data related to local potentials (human resources and natural resources), development policies and community welfare in the last 3 years in Merangin Regency (2016-2018). As an effort to analyze the data that has been obtained and collected, qualitative data analysis techniques are used in three ways, namely: data reduction, data presentation/displaying, and conclusions [11].

\section{Result and Discussions}

\subsection{The Concept of Political Policy}

Talking about policy politics is closely related to the discussion about the government. This is because as a party that is constitutionally handed over by the state management task. In relation to the above, there are various kinds of the government is required to be able to present a variety of development policies that can overcome the problems faced by the community. This is in line with the statement of a Professor from Harvard University, Prof. Michael Porter, who stated that the effectiveness of the management of the state carried out by a government is very dependent on the policy that it occupies. [12] That is, the role of the government is very necessary in an effort to release the people from the confines of the problems they face in this life. Understanding of public policy which were raised by several parties. Thomas R. Dye [13] who is considered one of the scholars of policy studies, for example, said that public policy is what the government does or does not do to overcome the problems faced by its people. Dye's statement is in line with the same similar understanding expressed by Bridgman and Davis related to public policy. Therefore, Subarsono [14] came to the conclusion that public policy is produced by government institutions, not from the private sector and is a choice that must be made or not done by the government. Meanwhile, Horald Laswell and Abraham Kaplan (in Nugroho, [12])define public policy as a program that is projected with certain goals, values and practices. On the other hand, Steven A. Peterson (in Nugroho [12]) interpreted public policy simply by taking it as an action taken by the government to overcome various problems. Policies are essentially decisions that directly regulate the management and distribution of natural, financial, and human resources in the public interest [15]. Public policy refers to a term or 
concept to explain certain specific action options that are very specific, such as in certain fields in public facilities sectors.

The above meanings look very diverse, so that a simpler understanding is needed as a form of synthesis of a series of definitions proposed by various experts above. Therefore, Riant Nugroho [12] interpreted public policy as every decision made by the state, as a strategy to realize the goals of the country. This simple understanding contains aspects of strategy, as the main component of public policy. The emergence of a strategy in this definition implies that a policy contains the political preferences of the actors involved in it and is not only positive, but also negative which implies accepting one and rejecting the other. In line with the above, Agustino [16] concludes that public policy is an action carried out by the authorities, has a specific purpose or purpose, is not random or planned, has goals and is goal-oriented, and is based on applicable rules.

Political discourse on policy has increasingly found its special place in the era of decentralization which was rolled out in post-reform Indonesia. This is of course as an implication of the submission of most of the duties and responsibilities of the central government to regional governments. According to Bird and Vaillancourt [2] regional autonomy was chosen as a development approach in post-New Order Indonesia because it promised to occur: economic efficiency, program cost effectiveness, accountability, increased resource mobilization, reduced disparity, increased political participation, and strengthening democracy and political stability. Through decentralization, local governments play a greater role in development because they now have the authority and responsibility to carry out community development in their jurisdiction. Because local governments are considered to have better knowledge of the needs and preferences of their citizens, the development process in the decentralization policy model should be more efficient than the centralized policy model in the framework of improving the welfare of local communities. This is because in the decentralization policy, local governments can better allocate resources to meet people's needs. Thus, theoretically, as stated earlier that the decentralization policy model should be able to bring a better level of welfare compared to a centralized (centralized) system. This is none other than because local governments that already have broad authority in regional management in the regional autonomy system are expected to produce public policies in the form of development programs.

\subsection{The Concept of Local Potential Development}

Development is interpreted simply as a change in a direction that is better and more advanced than the previous period [17]. Meanwhile, Tjokrowinoto [18] interpreted development as a series of efforts or steps to advance the condition of the community of a region or region with certain development concepts. Furthermore, it is said that development is a set of human efforts to direct social and cultural change in accordance with the goals of the life of the nation and state, namely to achieve the growth of civilization in social and cultural life on the basis of predetermined targets [17].

In an effort to change a region to be better than before, several development models are applied. Modernization theory which relies on the success of Western countries which is used as a role model for Eastern countries is one of the earliest development models. [19] According to Modernization, development in Eastern countries must be carried out by adopting the culture and structure that exists in Western society. This claim was later refuted by Dependentia's theory based on the failure of development in Latin American countries that adopted the principles of modernization. For the theory originating from these Left thoughts, the progress of the Eastern 
countries is only possible by breaking away from dependence on Western countries. The debate between the two main streams of development theory at a later stage gave birth to another development. The presence of alternative development theories is a consequence of finding many weaknesses of modernization and dependence.

Alternative development theories come in various forms, one of which is local potentialbased development that relies on the concept of ethnic-oriented development [20]. The development model born from the thoughts of Rodolfo Stevenhagen is an approach that puts forward the efforts to develop the potential of various ethnic groups and regions. Based on this concept, true development comes from within (local government and society) by relying on their potentials. Areas that have certain potentials (natural resources and human resources) can apply development models that are in accordance with their characteristics. The hope, by relying on sources originating from within the region, then everyone feels ownership and development goals will be achieved properly.

\subsection{The Concept of Welfare}

The discussion on welfare is closely related to social welfare which is an academic terminology that is more widely used. Social welfare is a good living condition, the fulfillment of material needs for life, spiritual needs (not enough to confess religion but a tangible manifestation of religion such as respecting others), social needs such as order, conflict in life can be managed, security can guaranteed, justice can be enforced where everyone has the same position before the law, reduced socio-economic disparities.

Midgley [21] states that there are three categories of achievement regarding welfare, namely first, the extent to which social problems can be regulated. Second, the extent to which needs can be met and third, the extent to which opportunities to improve living standards can be obtained. All of this can be created in shared life, both at the family, community and society level. Legally, the party most responsible for social welfare is the state. Law No. 11 concerning Social Welfare states that the implementation of social welfare is prioritized on poverty, neglect, disability, remoteness, social disability (behavior deviation), disaster victims, victims of violence, exploitation and discrimination.

In an effort to find out in conditions such as whether someone is said to be prosperous, then certainly what is needed is the indicator. According to Amartya Sen [22], the main indicators of prosperity are welfare economics, which is a rational process towards releasing people from obstacles to make progress. Social welfare can be measured by measures such as levels of living, fulfillment of basic needs (basic needs fulfillment), quality of life (quality of life) and human development (human development).

This study only focuses on three welfare indicators, namely poverty rates, crime rates, school enrollment rates, illiteracy rates, life expectancy rates, and unemployment rates. This is because these indicators are representative enough to see the welfare of the community in a region. The economic aspect is represented by poverty and crime rates, the education aspect appears in the school net enrollment rate and illiteracy rates, health aspects appear in the life expectancy rate and aspects of labor appear in the unemployment rate.

\subsection{The Local Potential Development of Merangin Regency}

Merangin Regency is one of the districts in Jambi Province and geographically bordering the Bungo Regency in the north, Sarolangun Regency in the east, Lebong Regency in the south 
and Kerinci Regency in the west. Overall the area of Merangin Regency is $7,679 \mathrm{~km}^{2}$ consisting of 24 sub-districts and 372,205 inhabitants.

As the largest region in Jambi Province, Merangin Regency has a variety of potential natural resources that are suitable for the orientation of regional development. Merangin Regency has 4 superior commodities which are the backbone of the population's economy in one of the western districts of Jambi Province, namely rubber, oil palm, coffee and coconut. Based on BPS data [23], the area of rubber in Merangin Regency was 132,192 hectares, oil palm covering 53,792 hectares, robusta coffee with an area of 10,860 hectares and coconut with an area of 1,658 hectares.

As the party entrusted with the task of managing the area, The Government of Merangin Regency should be able to use its local potential as a basis for regional development. This is in line with the concept of local potential-based development which relies on the understanding that real development comes from within (local government and society) by relying on their potentials. Areas that have certain potentials (natural resources and human resources) can apply development models that are in accordance with their characteristics. The hope, by relying on sources originating from within the region, then everyone feels ownership and development goals in the form of welfare will be achieved well.

Related to this, based on BPS Merangin data [23], there were 101,866 people working in the agricultural sector (mainly rubber, oil palm, coconut and coffee) with 36,905 heads of families (KK). That is, by focusing development on these three main commodities, The Government of Merangin Regency has helped the lives of most of its population. In this way, the level of welfare of the people of Merangin Regency will also increase because the main source has been well managed by the local government as the main controller at the regional level. This is in line with Midgley [21] stating that there are three categories of achievement regarding welfare, namely regulation of social problems, fulfillment of needs and the acquisition of opportunities to improve living standards. This method can be carried out jointly, both by the family, community and society at large, including the local government.

After the local potential to be managed for regional development and welfare assumptions to be achieved is known, then the next is what is the real form of policy that will be carried out by The Government of Merangin Regency to make it happen. In line with Riant Nugroho [12] who interpreted public policy as every decision made by the state / region to realize its objectives, The Government of Merangin Regency must make a policy so that these local potentials can be more useful for community development. The efforts made by The Government of Merangin Regency are based on The Deglobalization Concept carried out by Walden Bello [24] and run by an innovative bureaucratic-solution system such as that of Dernhart [25].

Based on The Deglobalization Concept of Bello [24] which relies on local needs, The Government of Merangin Regency can orient the management of regional potentials to meet domestic needs. As is known that domestic demand for rubber, oil palm, coconut and coffee commodities is very large and has increased every year. Rubber in Merangin Regency produces 61,360 tons / year, while the demand for palm oil raw materials requires 54.6 million tons, but it can only be fulfilled as much as 52.8 million tons, while coconut requires 20-21 billion heads and only 12 billion can only, while the need for coffee is 1.1 kilograms $(\mathrm{kg})$ per capita per year. This effort is certainly not easy, therefore it requires an innovative regional apparatus based on the concept of the New Public Service carried out by Dernhart [25].

Efforts to build regions based on local potential in Merangin Regency are getting stronger with the vision and mission carried out by the widest region in Jambi Province. As a form of accommodation towards the desire to develop the region for the better, The Government of 
Merangin Regency established a vision of 'Improving Towards Gold Mining' which stands for 'building the people's economy, clean and trustful towards Merangin, an advanced economy. safe, fair and prosperous'. As an effort to realize this great vision, The Government of Merangin Regency solidified its mission as outlined in the following 5 strategic steps: Improving the quality of bureaucratic services to the community by promoting transparency, efficiency, effectiveness and accountability; Improve the quality of basic service infrastructure; Improving the quality of human resources through education and health; Improve small-scale businessbased people's economic development and agricultural agribusiness; and Increasing the achievements of the younger generation and gender welfare.

Derivative activities from the implementation of strategic steps summarized in the above mission have been carried out quite a lot. Among these activities are improvements to road infrastructure in various Merangin Regency areas, improvement of education and health facilities and infrastructure and capacity building for village officials through The Village Financial System Training (Siskeudes). However, there is one policy that is directly related to development based on local potential, especially in agriculture, which has been carried out by The Government of Merangin Regency. The policy in question is the Establishment of a Regional-Owned Enterprise (BUMD) Preparation Team for PT. Merangin Bima Tama through the Decree of Merangin Regent Number 20/Pereko dan SDA/2018.

Directly, the existence of this BUMD has not yet had an impact on the economy of the Merangin Regency community in general. However, if you pay attention to the motives behind the formation of this BUMD Management Team, it is worthy of appreciation. This is because the existence of BUMD is expected to be a kind of beneficiary of a variety of potential natural resources in Merangin Regency. Its existence is intended as a reservoir of rubber, coconut and coffee produced by the community to be processed into a variety of products that have competitive selling points. In addition, this BUMD functions as a pruner for the many parties involved in the chain of management of rubber, coconut and coffee in Merangin Regency so that the benefits obtained by the community are reduced. Nonetheless, the Government of Merangin Regency through the relevant agencies must always encourage the improvement of the quality of products produced by the community through a series of training and counseling. Related to this, the strategic steps that can be taken by The Government of Merangin Regency are educating the people to improve the quality of management of rubber, mustard palm, coconut and coffee. This effort can be carried out through the implementation of a variety of training in the management of rubber, mustard palm, coconut and coffee that are of high quality and in accordance with consumer needs. The Government of Merangin Regency can also form a regional company (BUMD) that is able to process raw materials produced by the people, especially rubber, coconut and coffee, so as to produce not only one product, but in a variety of variations. Related to this, rubber raw materials, for example, can be developed as an asphalt mixture that is very successful in Malaysia and Thailand. The same can be applied to coconut and coffee raw materials that can produce a variety of products if processed in professional ways and utilize the latest technology. In short, orienting development to regional potential with professional management, the welfare of the community can be realized as desired with the implementation of regional autonomy.

\section{Conclussion}


Regional autonomy provides space for Merangin Regency to develop its regional potential so that it is more beneficial to people's welfare. Rubber, oil palm, coconut and coffee are regional potentials which must be the orientation of development in Merangin Regency. With the development of these three commodities using a series of innovative-solution policies, it is expected that the welfare of the people in this region will increase.

\section{References}

[1] G. Stoker, The politics of local government. Macmillan International Higher Education, 1991.

[2] R. M. Bird and F. Vaillancourt, Fiscal decentralization in developing countries. Cambridge University Press, 2008.

[3] Z. A. Kisman and I. Tasar, "The key elements of local development," Procedia Econ. Financ., vol. 15, pp. 1689-1696, 2014.

[4] J. Witkowski and M. Kiba-Janiak, "The role of local governments in the development of city logistics," Procedia-Social Behav. Sci., vol. 125, pp. 373-385, 2014.

[5] W. Nak-ai, U. Jiawiwatkul, L. Temsirikulchia, and K. Nontapattamadul, "Community public policy process for solving cadmium contamination problems in the environment: A case study of Mae Sod district, Tak province," Kasetsart J. Soc. Sci., vol. 39, no. 1, pp. 59-66, 2018.

[6] C. K. Sharma, "Reimagining Federalism in India: Exploring the Frontiers of Collaborative Federal Architecture," 2015.

[7] B. B. C. Brillo, "The Politics of Lake Governance: Sampaloc Lake, Pandin Lake and Tadlac Lake of the Laguna De Bay Region, Philippines," Brillo, BB (2017). Polit. Lake Gov. Sampaloc Lake, Pandin Lake Tadlac Lake Laguna Bay Reg. Philipp. Asia-Pacific Soc. Sci. Rev., vol. 17, no. 1, pp. 66-79, 2017.

[8] Y. Hasjimzum, "Model Demokrasi dalam Peningkatan Kualitas Pelayanan Publik (Studi Otonomi Daerah dalam Peningkatan Kesejahteraan Masyarakat Pasca Reformasi)," J. Din. Huk., vol. 14, no. 3, pp. 445-457, 2014.

[9] K. Tasrin and P. Wulandari, "Kajian Pengaruh Kebijakan Desentralisasi Pada Peningkatan Kesejahteraan Masyarakat (Studi Kasus: Kabupaten/Kota di Provinsi Jawa Barat)," J. Borneo Adm., vol. 8, no. 2, 2012.

[10] H. M. Pahrudin, "The Study of Government's Role for Welfaring Rubber Farmer in the Globalization Vortex," J. Ilmu Sos. dan Ilmu Polit., vol. 21, no. 2, pp. 117-131, 2017.

[11] M. B. Miles and A. M. Huberman, "Analisis Data Kualitatif. Terjemahan Tjetjep Rohendi Rohidi," Jakarta Penerbit Univ. Indones., 1992.

[12] R. Nugroho, "Public Policy: Dinamika Kebijakan, Analisis Kebijakan, Manajemen Kebijakan," Jakarta Elex Media Komputindo, 2011.

[13] T. R. Dye, Understanding Public Policy. England: Prentice-Hall, Inc., 1990.

[14] A. G. Subarsono, Analisis kebijakan publik: konsep, teori dan aplikasi. Pustaka Pelajar, 2005.

[15] E. Suharto, Membangun masyarakat, memberdayakan rakyat: Kajian strategis pembangunan kesejahteraan sosial dan pekerjaan sosial. Refika Aditama, 2005.

[16] L. Agustino, "Dasar-dasar kebijakan publik (Edisi Revisi)," Alf. Bandung, 2016.

[17] A. N. Jamaludin, "Sosiologi Pembangunan." Pustaka Setia, 2016.

[18] M. Tjokrowinoto, Pembangunan: dilema dan tantangan. Pustaka Pelajar, 2004.

[19] B. Hettne, Development theory and the three worlds: towards an international political economy of development. Longman Scientific and Technical, 1990.

[20] M. Amien, Kemandirian lokal: konsepsi pembangunan, organisasi, dan pendidikan dari perspektif sains baru. Gramedia Pustaka Utama, 2005.

[21] J. Midgley, Social development: The developmental perspective in social welfare. Sage, 1995.

[22] A. Sen, Development as Freedom. New York: Anchor Books, A division of Random House Inc., 2002.

[23] "Badan Pusat Statistik Kabupaten Merangin. Kabupaten Merangin Dalam Angka 2018,” BPS. . 
[24] W. Bello, Deglobalization: Ideas for a new world economy. Zed Books Ltd., 2008.

[25] J. V Dernhart and B. D. Robert, "The new public service: serving, not steering," ME Sharpe, New York, 2003. 